Resumen por el autor, George B. Wislocki, Johns Hopkins Medical School.

Observaciones sobre el comportamiento de la tinta china inyectada en animales durante la preñez.

Experimentos llevados a cabo durante muchos años han venido a demostrar que las partículas inertes que flotan en la circulación materna no pueden atravesar la placenta y penetrar en el feto. La explicación de este fenómeno, mediante el cual el material en suspensión no atraviesa la placenta o las membranas fetales, no ha sido hallada más que para un grupo de substancias, esto es, los colorantes vitales. Estos colorantes, conforme Goldmann ha demostrado en el caso de la rata y ratón, son absorbidos y acumulados en el epitelio coriónico y las células de la membrana vitelina, y de este modo se previene su penetración en el feto. El autor ha inyectado gránulos de carbón suspendidos en acacia (tinta china) en una serie de conejillos de indias, conejos, gatos y perros preñados. Los animales fueron sacrificados después de unos cuántos dias y los tejidos examinados. El autor ha podido observar que los gránulos de carbón se depositan en el hígado, bazo, pulmones y médula ósea de la madre. En la placenta, membranas fetales y organos de los fetos no pudo hallar carbón, ni aún estudiándolos bajo el microscopio. La conclusión que se deriva de la repulsión de las partículas de tinta por las células de la placenta y membranas fetales es que dichas células son incapaces de absorber o fagocitar material extraño de tamaño grosero, flotante en la sangre. El límite del tamaño de las partículas que pueden absorber debe estar localizado entre el de una suspensión grosera, tal como la tinta china, y una dispersión ultramicroscópica, como el azul trypan.

Translation by Jose F. Nonidez

Cornell Medical College, New York 
A CTHOR'B ABSTRACT OF THIS PAPER ISSTED

BY THE BIBLIOGRAPHIC SERVICE, MARCH 28

\section{OBSERVATIONS UPON THE BEHAVIOR OF CARBON GRANULES INJECTED INTO PREGNANT ANIMALS}

GEORGE B. WISLOCKI

Department of Anatomy, Johns Hopkins Medical School

It has long been known that certain cells of the body possess the power of removing foreign particulate matter from the bloodstream. Thus, when foreign particles, such as the carbon granules of india ink, are injected into the circulation of an animal, they are completely removed from the blood-stream in a remarkably short period of time. Gross and microscopic examination of the tissues of the animal reveals that the endothelial cells in certain organs have removed the ink from the circulation. The endothelial cells lining the sinusoidal channels of the liver and spleen are found heavily laden with the foreign particles. In addition to the granules of carbon which have been actually phagocytized, aggregations of the particulate matter into tiny clumps are found within the lumen of the blood sinuses. The bone-marrow in many animals is the site of a similar but subordinate process.

The question of the behavior of the cells of the placenta toward particulate matter circulating in the blood-stream has been only incompletely investigated. Recent writers on the problem of placental transmission, namely, Zuntz ('04), Kehrer ('08), and Hofbauer ('10), concur in the statement that particulate matter does not pass from the maternal into the fetal bloodstream. The explanation of the failure of suspended material to pass through the placenta or fetal membranes has not been given except-for one group of substances, namely, the vital dyes. The vital dyes, which are ultramicroscopic dispersions of certain of the acid azo dyes have been rather fully investigated by Goldmann ('09). He showed that when these dyes are introduced into the blood-stream of a pregnant mouse or rat, 
they stain the maternal tissues, the placenta, and the outermost fetal membrane, but fail to stain the fetus. He discovered that the reason for this apparently was that the dye-stuffs were absorbed and stored by the cells of the chorion and vitelline membrane and thereby prevented from entering the fetus.

It has, however, not been determined whether more coarsely dispersed substances than the 'vital dyes,' such as the carbon granules of india ink, are similarly phagocytized and stored by the cells of the placenta and fetal membranes or whether they are completely rejected by these cells. In the literature one finds numerous brief statements regarding the fate of coarse particulate substances injected into the blood-stream of pregnant animals. The earlier experimental work is surprisingly contradictory and but little importance can be assigned to most of it, as the observations were made on an insufficient number of animals and the methods employed were often open to criticism. Thus, Reitz ('68) described cinnabar (red sulphide of mercury) in the tissues of a rabbit fetus after injecting the mother; Caspary ('77) reported a similar result with cinnabar in a rabbit; Perls (77) recorded the passage of cinnabar and ultramarine into the fetuses in several rabbits and dogs; Mars ('80) observed the passage of a number of emulsified substances into rabbit fetuses, and, finally, Pyle ('84) stated that he observed the passage of ultramarine into a series of rabbit fetuses.

On the other hand, Hoffmann and Langhan ('69) failed to find cinnabar in the fetuses of a rabbit which they injected; Fehling ('77) and Ahlfeld ('77) reported the failure to find india ink in the liver, kidneys, or blood of the fetuses of several rabbits, and Miropolsky ('85) obtained similar negative results with cinnabar.

Krukenberg ('88), who can be said to have undertaken the first thorough investigation of this kind, injected a suspension of barium sulphate into one series of pregnant rabbits and a non-pathogenic organism, B. prodigiosus, into another series. Neither particles of barium sulphate nor organisms were recoverable from the tissues of the fetuses. His experiments left little doubt that particulate materials, such as he employed, are not transmitted from mother to fetus. 
Hofbauer ('10) obtained similar results after injecting colloidal silver and silicium into several pregnant animals. Neither of the substances could be found in the fetal organs.

Finally, Goldmann ('09) undertook his experiments with acid azo dyes, and showed that they, too, were not transmitted to the fetus. Goldmann's report contains the only description of the microscopic examination of the placenta and fetal membranes. In the mouse and rat the giant-cells, the chorionic ectoderm of the labyrinth, and the epithelium of the vitelline membrane were found heavily laden with granules of dye; these cellular accumulations of the dye-stuff were looked upon as evidencing the protective mechanisms of the fetus.

In the present experiments a filtered solution of india ink was used. The ink was administered intravenously to a series of pregnant animals, consisting of one dog, three cats, three rabbits, and three guinea-pigs. The amount of ink injected was regulated according to the size of the animals, the guinea-pigs receiving 1 cc., the rabbits and cats 5 cc., the dog 15 cc., on two successive days. The animals were sacrificed one or two days after the last injection.

The gross distribution of the india ink was essentially the same in all the species of animals examined. At autopsy the liver and spleen were found to be deep black and the lungs presented a grayish appearance. The bone-marrow in the rabbit was of the same color as the liver and spleen; in the guinea-pig it was not so black, while in the cat and dog its color appeared to be normal. The uterus appeared unstained. The placentae, fetal membranes, and the fetuses showed nothing to the naked eye suggesting the presence of ink particles in these tissues. The remaining organs and tissues of the animals appeared normal. The findings in gross, therefore, indicated that the injected ink granules had in whole or greater part been segregated in the liver, spleen, bone-marrow, and lungs, and that none had been deposited in the placentae, fetal membranes, or fetuses.

Microscopic examination revealed the characteristic deposition of the carbon particles in the endothelial phagocytes of the liver, spleen, and bone-marrow. Particles, in part free and in part 
phagocytized, were also found, to a slight extent, in the interalveolar septa of the lungs. In the remaining organs and tissues of the body, with the exception of a few particles occasionally caught in a blood vessel or phagocytized within an endothelial cell, the carbon granules of the india ink were conspicuously absent.

No carbon particles could be found on examining the placentae. The chorionic epithelium, which in varying patterns is the predominating tissue in them all, showed no evidence of having absorbed particles of ink. The endothelial cells, which in the cat's and dog's placentae completely line the maternal vessels, had not the power of phagocytizing ink particles as had the endothelium of the liver, spleen, and bone-marrow. None of the ink-particles had agglutinated in either the maternal vessels of the dog's and cat's placentae, or in the corresponding sinuses of the rabbit's and guinea-pig's placentae, as they do in the sinuses of the liver and spleen. In the columnar cells of the chorion which flank the placentae of the dog and cat, known respectively as the 'green' and 'brown borders,' no carbon was visible. Nor were particles of ink discovered in the cells covering the vitelline membrane which in the rabbit and guinea-pig forms the outermost fetal membrane and faces the uterine mucosa.

The absence of particles of india ink in all these localities is surprising, since in vitally stained animals these same cells, namely, the chorionic epithelium and the epithelium of the vitelline membrane, are heavily laden with minute granules of trypan blue.

The conclusion to be drawn from the rejection of the ink particles by the cells of the placentae and fetal membranes is that they are incapable of absorbing or phagocytizing coarse, foreign particulate matter afloat in the blood-stream. The limit of the size of particles which they are capable of accepting must lie somewhere between that of a coarse suspension, such as india ink, and an ultramicroscopic dispersion, such as trypan blue. Trypan blue in turn, although absorbed by the chorionic epithelium and fetal membranes, is incapable of entering the 
fetal circulation as true solutions have been shown readily to do. Trypan blue, however, may be on the border line of transmissibility, since traces of it actually enter the fetal circulation in the rabbit and guinea-pig.

\section{LITERATURE CITED}

Ahlfeld, F. 1887 Zur Frage ueber den Uebergang geformter Elemente von Mutter auf Kind. Centralbl. f. Gyn., Bd. 1, S. 265.

Caspary, J. 1877 Zur Genese der hereditären Syphilis. Vierteljahrresschr. f. Dermat u. Syph., Bd. 4, S. 491.

Fehling, H. 1877 Beitraege zur Physiologie des placentaren Stoffverkehrs. Arch. f Gyn., Bd. 11, S. 523.

Goldmann, E. E. 1909 Die aeussere und innere Sekretion des gesunden und kranken Organismus im Lichte der 'vitalen Faerbung.' Teil 1. Beitr. z. klin. Chir., Bd. 64, S. 192.

Hofbauer, J. 1905 Grundzüge einer Biologie der menschlichen Plazenta. Wien und Leipzig.

Hoffman, F. A., tnd P. Langerhans 1867 Ueber den Verbleib des in die Circulation eingeführten Zinnobers. Virchow's Archiv f. path. Anat., Bd. 48 , S. 304.

KeHRER, E. 1907 Der plazentare Stoffaustausch in seiner physiologischen und pathologischen Bedeutung. Wurz. Abhandl. a. d. Gesammtgeb. d. prakt. Med., Bd. 7, S. 17.

KRUKenberg, G. Experimentelle Untersuchungen über den Utbergang geformter Elemente von der Mutter zur Frucht. Arch. f. Gyn., Bd. 31, S. 313.

MARS, A. 1880 Ueber den Uebergang geformter Elemente aus dem Kreislauf der Mutter in den des Foetus. Jahresbericht ueber d. gesammte Med., Virchow-Hirsch, Bd. 1, S. 81.

Miropolsky, M. 1887 Du passage dans le sang du foetus des substances solides contennes dans le sang de la mere. Archives de Physiologie, T. 6, p. 101.

Perts 1879 Lehrbuch d. allgem. Pathol., Bd. 2, S. 266.

PyLe, J. P. 1884 An experimental research on the utero-placental circulation. Phila. Med. Times, vol. 14, p. 711.

REITZ, W. 1868 Ueber die passiven Wanderungen von Zinnoberkörnehen durch den thierischen Organismus. Berichte der Wiener Akad. Math. naturw. Classe, Bd. 57, S. 8.

Zuntz, L. 1908 Der Stoffaustausch zwischen Mutter und Frucht. Ergebnisse der Physiologie, Bd. 7, S. 403-443. 